\title{
PENGARUH PENGGUNAAN PANKREAS KAMBING AWETAN TERHADAP KEKUATAN TARIK DAN KEMULURAN KULIT KRAS KAMBING
}

\author{
Oleh : Muchtar Luttie, Bambang Wikantadi, \\ Soelistiyah Wiryodiningrat, Titik Harsiwi
}

\section{ABSTRACT}

Took 10 pieces salted goat skins which same quality, cut in 20 sides follow the back bone line divided into 5 groups, each group consist 4 sides. All this sample be processed to crust leather according to IRDLAI procedure. In bating processing the subtitute for oropon was cured of goat pancreas.

For 5 groups sample each used $0 ; 0,75 ; 1,5 ; 2,25$ and 3 procentage of cured pancreas. For tensile strength and stretch testing used the part of croupon, shoulder and belly. Analisis statistic using CRD nasted sample and factorial $3 \times 5$ and subsequently be done Tuk test. There was a real differences $(\mathrm{P}<0,01)$ between tensile strenght by effects of concentration of pancreas also with it's stretch.

The best consentration can be suggested were 0,$75 ; 1,5 ; 2,25$ procentage. Averege tensile strength for each of them were $183,2 \mathrm{Kg} / \mathrm{cm} 2 ; 177,3$ $\mathrm{Kg} / \mathrm{cm} 2$ and $207,1 \mathrm{Kg} / \mathrm{cm} 2$, and the stretch which close with the standart only on the concentration $2,25 \%$ that was $66,6 \%$. 


\section{PENDAHULUAN}

Hingga saat ini perusahaan-perusahaan penyamakan kulit di Indonesia selalu menggunakan Oropon (yang mengandung tripsin dan Amonium sulfat) yang harus diimport sebagai bahan untuk proses "bating" (Balai Penelitian Kulit, 1972). Padahal sebenarnya di Indonesia ada kemungkinan untuk mendapatkan pengganti oropon tersebut dengan jalan menggunakan bahan sisa dari hewan yang dipotong yaitu kelenjar pankreas (dari kambing misalnya), oleh karena kelenjar pankreas mengandung enzima-enzima proteolitek, terutama tripsin (Di Vakaran, 1978). Menurut Mann (1960), pankreas dapat diawet dengan serbuk gergaji dalam perbandingan $1: 1$. Wikantadi et al. (1978) menyarankan penggunaan pankreas awetan seperti yang dikatakan Mann (1960) tersebut sekitar 0,6 persen dari berat kulit.

Penelitian ini bertujuan untuk mencari konsentrasi pankreas awetan yang sesuai untuk proses bating sehingga menghasilkan kekuatan tarik dan kemuluran yang memenuhi standart.

\section{MATERI DAN METODA}

Diambil 10 lembar kulit kambing garaman yang sama kwalitasnya, dibelah menjadi 20 belahan menurut garis punggung untuk dikelompokkan menjadi 5 kelompok yang masing-masing terdiri atas 4 belahan.

Semua sample mengalami perlakuan yang sama untuk diproses menjadi kulit kras sesuai dengan ketentuan Balai Penelitian Kulit (BPK). Hanya pada proses bating diberi perlakuan yang berbeda dan tidak menggunakan oropon, tetapi sebagaigantinya digunakan pankreas kambing awetan seperti disarankan Mann (1960). Untuk kelima kelompok belahan kulit masingmasing di Bate dengan menggunakan $0 ; 0,75 ; 1,5 ; 2,25$; dan 3 persen pankreas kambing awetan. Untuk pengujian kekuatan tarik dan kemuluran diambil contoh kulit dari daerah krupon, perut, dan leher, menurut BPK (1972).

Pola percobaan ini menggunakan Completely Randomitzed Design (C.R.D.) rested sample untuk kulit bagian krupon sedangkan rata-rata pengujian fisik kulit bagian krupon, perut, dan leher digunakan CRD factorial $3 \times 5$ yang kemudian dilakukan test Tukey (Snedecor dan Cochran, 1964). Penelitian ini dilaksanakan di Balai Penelitian Kulit pada bulan Juli Agustus 1978.

\section{HASIL DAN PEMBAHASAN}

Hasil selengkapnya pengujian kekuatan tarik daerah krupon, perut dan leher dapat dilihat pada tabel 1 . 


\section{Kekuatan Tarik}

Tabel 1. Hasil pengujian kekuatan tarik ( $\mathrm{Kg} / \mathrm{Cm} 2$ ).

\begin{tabular}{c|c|c|c|c|c}
\hline \multirow{2}{*}{ Daerah } & \multicolumn{5}{|c}{ Konsentrasi Pankreas (\%) } \\
\cline { 2 - 6 } & 0,00 & 0,75 & 1,50 & 2,25 & 3,00 \\
\hline \multirow{4}{*}{ Krupon } & 173,30 & 212,57 & 193,83 & 214,43 & 167,40 \\
& 176,80 & 117,53 & 182,10 & 241,53 & 204,00 \\
& 217,00 & 244,00 & 256,30 & 234,80 & 221,40 \\
& 167,20 & 266,53 & 214,90 & 240,03 & 127,90 \\
\hline \multirow{5}{*}{ Perut } & 188,53 & 154,93 & 206,63 & 174,37 & 127,70 \\
& 167,18 & 218,37 & 87,63 & 173,67 & 206,50 \\
& 253,13 & 183,27 & 213,50 & 200,87 & 175,83 \\
& 140,87 & 157,60 & 168,77 & 243,80 & 68,93 \\
\hline \multirow{5}{*}{ Leher } & 137,63 & 124,07 & 171,83 & 197,80 & 85,03 \\
& 145,47 & 156,80 & 149,53 & 241,77 & 106,43 \\
& 184,03 & 199,13 & 171,30 & 148,13 & 114,83 \\
& 170,70 & 130,70 & 151,47 & 171,53 & 48,20 \\
\hline
\end{tabular}

Tabel 2. Analisa Varians kekuatan tarik bagian krupon

\begin{tabular}{l|r|r|r|r}
\hline \multicolumn{1}{c|}{ Sumber Variasi } & df & SS & MS & F \\
\hline Treatment & 4 & 24813,273 & 6203,318 & 1,738 \\
Sample & 15 & 53527,698 & 3568,513 & 2,342 \\
Error & 40 & 60922,634 & 1523,565 & - \\
Total & 59 & 139263,605 & - & - \\
\hline
\end{tabular}

Dari tabel 1 ternyata bahwa kekuatan tarik kulit bagian krupon sebagai akibat perbedaan konsentrasi pankreas yang digunakan tidak berbeda (P $<0,01$ ). Rata-rata kekuatan tarik kulit daerah krupon untuk konsentrasikonsentrasi pankreas $0 ; 0,75 ; 1,5 ; 2,25$ dan 3 persen masing-masing adalah 183,$57 ; 218,66 ; 211,73 ; 232,58$ dan $180,17 \mathrm{Kg} / \mathrm{Cm} 2$.

Bila harga-harga itu dibandingkan dengan standar ( $=100 \mathrm{Kg} / \mathrm{Cm} 2)$ maka semuanya memenuhi syarat. Daridata itu terlihat bahwa kekuatan tarik yang tertinggi dijumpai pada konsentrasi $0,75 \%$ sampai dengan $2,25 \%$. Konsentrasi itu lebih tinggi dari yang disarankan Wikantadi et.al. (1978). Diduga hal ini terjadi karena percampuran antara pankreas dengan serbuk gergaj dalam penelitian ini kurang homogen, sehinggga kerja enzima kurang efektif.

Majalah Barang Kulit, Karet dan Plastik
Tabel 2. menunjukkan bahwa konsentrasi pankreas yang berbeda menimbulkan perbedaan sangat nyata $(\mathrm{P}<0,01)$ antara kekuatan tarik. Sedangkan perbedaan letak pengambilan sampel (krupon, perut, dan leher) juga menimbulkan perbedaan yang sangat nyata $(P<0,01)$ antara kekuatan tarik. Ternyata interaksi antara kedua treatment tidak nyata $(P<0,05)$.

Tabel 3. Analisa Varians kekuatan tarik rata-rata bagian krupon, perut dan leher

\begin{tabular}{|c|c|c|c|c|}
\hline Sumber variasi & $\mathrm{df}$ & SS & MS & $\mathrm{F}$ \\
\hline Treatment & 14 & 59855,721 & & \\
\hline Konsentrasi (K) & 4 & 23550,324 & 5287,58 & 4,223 ** \\
\hline Letak & 2 & 31080,652 & 15540,326 & $11,146^{* *}$ \\
\hline $\mathrm{K} \times \mathrm{L}$ & 8 & 5224,745 & 653,09 & 0,468 \\
\hline Error & 45 & 62738,628 & 1394,19 & \\
\hline
\end{tabular}

** Berbeda sangat nyata $(\mathrm{P}<0,01)$

Analisa statistika lebih lanjut dengan Test Tukey menunjukkan bahwa terdapat perbedaan sangat nyata $(P<0,01)$ antara kekuatan tarik akibat penggunaan konsentrasi pankreas $2,25 \%$ dengan $3 \%$ demikian pula antara bagian krupon dengan leher.

\section{Kemuluran}

Hasil pengujian kemuluran dapat dilihat pada tabel 4 . Ternyata setelah kemuluran bagian krupon dianalisa dengan analisa Varians (tabel 5.) tidak terdapat perbedaan akibat perbedaan konsentrasi pankreas $(\mathrm{P}<0,05)$. Ratarata kemuluran untuk konsentrasi-konsentrasi pankreas 0,$0 ; 0,75 ; 1,5 ; 2,25$; dan 3,00 persen masing-masing adalah 52,$7 ; 66,22 ; 62,5 ; 66,3$ dan 46,8 persen. Ternyata yang memenuhi standar pada konsentrasi-konsentrasi 0,0 dan 3,0 persen. Konsentrasi ini jauh lebih besar dari pada yang telah diteliti oleh Wikantadi et.al. (1978). Diduga sebabnya seperti telah diterangkan dalam kekuatan tarik.

Rata-rata kemuluran bagian krupon, perut dan leher setelah dianalisa dengan analisa Varians dari pola faktorial $3 \times 5$ (tabel 5.), maka perbedaan konsentrasi pankreas menimbulkan pengaruh yang sangat nyata $(P<0,01)$ terhadap kemulurannya. Demikian pula perbedaan letak daerah pengambilan sampel (krupon, perut dan leher) menimbulkan perbedaan yang sangat nyata $(\mathrm{P}<0,01)$ terhadap kemulurannya. Interaksi sangat nyata $(\mathrm{P}<0,01)$ dijumpai antara treatment.

Vol. VI. No. 10-11 1990/1991 
Bilamana kemuluran rata-rata dibandingkan dengan standar mutu maksimal $=60$ persen) maka yang memenuhi syarat seperti standar hayalah konsentrasi pankreas 3,0 persen.

Analisa statistika lebih lanjut dengan test Tukey menunjukan bahwa erdapat perbedaan kemuluran yang sangat nyata $(\mathrm{P}<0,01)$ antara konentrasi $0,0 \%$ dengan $3,0 \% ; 1,5 \%$ dan 2,25\% antara krupon dan leher, ntara krupon yang di bate dengan pankreas awetan 3,0\% dengan perut ang di bate $0,0 \%$ dan $1,5 \%$. Terdapat perbedaan yang nyata $(P<0,05)$ intara bagian leher yang di bate 3,0\% dengan bagian perut yang di bate , $0 \% ; 1,5 \%$; dan $2,25 \%$.

\section{KESIMPULAN}

Konsentrasi pankreas yang dapat dianjurkan adalah antara $0,75-2,25$ ersen bilamana diinginkan kekuatan tarik yang tinggi. Bila diinginkan kenuluran yang memenuhi standar dipilih konsentrasi $2,25 \%$.

\section{Tabel 4. Hasil pengujian kemuluran (\%)}

\begin{tabular}{l|c|c|c|c|c}
\hline \multirow{2}{*}{$\begin{array}{l}\text { Daerah peng- } \\
\text { ambilan }\end{array}$} & \multicolumn{5}{|c}{ Konsentrasi pankreas (\%) } \\
\cline { 2 - 6 } Sample & 0,00 & 0,75 & 1,50 & 2,25 & 3,00 \\
\hline \multirow{4}{*}{ Krupon } & 83,0 & 66,0 & 57,0 & 68,0 & 49,7 \\
& 58,3 & 60,0 & 65,7 & 58,7 & 46,0 \\
& 66,3 & 71,3 & 64,0 & 74,0 & 38,0 \\
& 75,0 & 67,3 & 63,0 & 64,3 & 53,3 \\
& & & & & \\
& 89,0 & 69,0 & 64,3 & 81,3 & 66,3 \\
Perut & 73,7 & 59,3 & 91,3 & 72,7 & 59,3 \\
& 65,7 & 61,3 & 88,0 & 85,0 & 57,0 \\
& 88,7 & 84,3 & 82,7 & 70,3 & 69,0 \\
& & & & & \\
\hline & 70,7 & 72,7 & 68,0 & 76,3 & 52,3 \\
& 68,0 & 57,7 & 75,7 & 64,0 & 56,0 \\
& 72,0 & 62,0 & 64,0 & 68,7 & 39,6 \\
& 63,0 & 68,3 & 69,3 & 65,7 & 56,0 \\
\hline
\end{tabular}

Tabel 5. Analisa Varians persentase kemuluran rata-rata bagian Krupon, Perut dan Leher

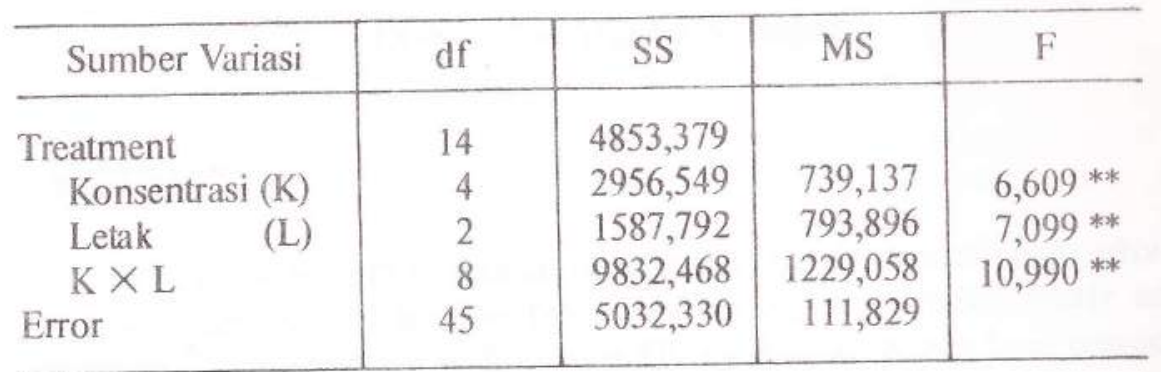

** Berbeda sangat nyata $(\mathrm{P}<0,001)$.

\section{DAFTAR PUSTAKA}

1. Balai Penelitian Kulit, "Kaleidoskop dari Kulit Hewan Mentah Hingga Barang Jadi", BPK, Yogyakarta, 1972.

2. Balai Penelitian Kulit, "Kulit Standar Indonesia", BPK, Yogyakarta, 1972.

3. Divakaran, $S$, "Pancreatic Bates In Processing And Utilization Of Animal By Products", FAO. Development paper No. 75. FAO., Rome, 1978.

4. Mann, I, "Rural Tanning Techniques", FAO., Rome, (90 - 115), 1960.

5. Snedecor, G.W. and W.G. Cochran, "Statistical Methods", The Iowa State University Press. Ames, Iowa USA, 1964.

6. Wikantaci, B, S, Djojowidagdo dan Soeparno, "Penggunaan Kelenjar Untuk Proses Bating Pada Kulit Kambing Yang Disamak Chrome", Laporan Penelitian Proyek PPPT - UGM. 1978- 1979 No. 34, Lembaga Penelitian UGM., 1979.

7. Bambang Wikantadi DKK "Riset Obat Bating dan Chrome", Laporan Penelitian Proyek Penelitian Balai Penelitian Kulit No. 08/BPK/1978 - 1979 DIP. No. 32/XIX/3/78. 